\title{
Modernization of Legislation on Control and Supervisory Activities in the Field of Land Management in the Russian Federation
}

\author{
L. P. Podbolotova*, O. V. Gvozdeva, L. V. Molodkina, A. I. Pyatov, A. A. Korostyleva \\ State University of Land Use Planning, 15, Kazakova str., Moscow, 105064, Russia
}

\begin{abstract}
The authors of the presented article consider the main changes in land legislation that occurred in 2020-2021 regarding the modernization of legislation on control and supervisory activities in the field of federal state land control (supervision). These changes require the study and attention of both public authorities and individuals and legal entities. The article analyzes the main provisions of the Federal Law of 11.06.2021 N 170-FZ "On Amending Certain Legislative Acts of the Russian Federation in Connection with the Adoption of the Federal Law "On State Control (supervision) and municipal control in the Russian Federation" regarding the implementation of state land control (supervision), as well as new documents adopted in its development. It is concluded that not only legislation changes, but also activities in the field of land control (supervision) as one of the main functions of land and other real estate management.
\end{abstract}

\section{Introduction}

Since the beginning of 2020, Federal Service of State Registration, Cadastre and Cartography has received "all the powers of the Ministry of Economic Development of Russia in the field of land relations, regulation of civil turnover of real estate, maintenance of the Unified State Register of Real Estate, state cadastral registration, registration of real estate rights, provision of data from the Unified State Register of Real Estate, cadastral assessment, land monitoring, land supervision, geodesy and cartography, creation and development of spatial data infrastructure and, and most importantly, their legal regulation" [14].

Determining the relevance of this study, we note that at present in Russia there have been significant changes in land legislation related to the modernization of legislation on control and supervisory activities in the field of federal state land control (supervision), which require the study and attention of both state bodies and individuals and legal entities.

Having analyzed the degree of development of science, it should be noted that over the past two years there have been quite a lot of works on the subject under consideration. Among the authors whose works were used in this scientific article, it should be noted S.A. Lipsky, Barsukova G.N., Kurdyumova M.D., Polyakova V.E., Yarotskaya E.V., Yurchenko K.A. and others. It should also be noted the very high-quality work of experts of the reference and legal system Consultant Plus, who prepare interesting reviews of land legislation that are accessible even to non-professionals.

\section{Research methodology}

The article provides an analysis of the main regulatory legal acts in force in the Russian Federation and regulating the implementation of land supervision in connection with the modernization of legislation on control and supervisory activities.

The methodology of this study includes empirical research methods that serve as a means of collecting specific facts in order to identify and describe phenomena (observation, conversation, interviews), as well as theoretical research methods that reveal the essence of the studied phenomena, reveal natural connections and relationships that are used in determining the problem and formulating research tasks (analysis, synthesis, abstraction, deduction, induction), etc.

\section{Discourses and scientific results}

Resolutions of the Government of the Russian Federation dated 12.04.2020 N 496, dated 07.09.2020 No. 1369 updated many acts of the Government of the Russian Federation on these issues [14]. For incomplete two years, for most paragraphs specified in Table 1 of the article "Change of powers of Federal Service of State Registration, Cadastre and Cartography in 2020 taking into account the decree of the Government of the Russian Federation of 07.09.2020 N 1369," the relevant orders of Federal Service of State Registration, Cadastre and Cartography were adopted, starting with the order of

Corresponding author: podbolotovalp@guz.ru 
Federal Service of State Registration, Cadastre and Cartography of 01.02.2021 N P/0034 "On approval of the Regulations of the Federal Service for State Registration, Cadastre and Cartography" and ending with specific areas of activity of Federal Service of State Registration, Cadastre and Cartography [14].

In addition, over the past two years, land legislation, urban planning legislation, as well as legislation on control and supervisory activities, including in the field of land and other real estate management, have significantly changed.

A number of federal laws have been adopted that amend existing regulatory acts. Among them:

1. Federal Law of $30.04 .2021 \mathrm{~N}$ 120-FZ "On Amendments to the Federal Law" On State Registration of Real Estate "and Certain Legislative Acts of the Russian Federation" (here in after - Law No. 120-FZ);

2. Federal Law of 11.06.2021 N 191-FZ "On Amendments to Certain Legislative Acts of the Russian Federation";

3. Federal Law of 11.06.2021 N 170-FZ "On Amending Certain Legislative Acts of the Russian Federation in Connection with the Adoption of the Federal Law" On State Control (Supervision) and Municipal Control in the Russian Federation "(hereinafter - Law No. 170-FZ) [3];

4. Federal Law of 01.07.2021 N 273-FZ "On Amendments to Certain Legislative Acts of the Russian Federation" [4];

5. Federal Law of 01.07.2021 N 275-FZ "On Amendments to Certain Legislative Acts of the Russian Federation," etc. [5].

The Federal Law of 30.04.2021 N 120-FZ introduced particularly many changes in the cadastral-registration industry of legislation aimed at protecting the constitutional rights of citizens and legal interests of legal entities in the field of real estate turnover [11]. Most of the changes envisaged by this came into force with 30.04.2021. Another part of the provisions comes into force with 28.10.2021 and some provisions with 01.01.2023.

Another important law amending land legislation is Act No. 170-FZ. Commencement of the law with 01.07.2021 (except for certain provisions). Article 50 of this law makes significant changes to the Land Code of Russia in terms of the implementation of federal state land control (supervision, hereinafter - land supervision), starting from a name change, ending with the adoption of a new decree of the Government of the Russian Federation dated 30.06.2021 N 1081 "On federal state land control (supervision)" (together with the "Regulation on federal state land control (supervision)")). The previous decree of the Government of the Russian Federation dated 02.01.2015 N 1, which approved the previously applied provision on state land supervision, was declared invalid [1.3].
Thus from 01.07.2021 in Russia in connection with adoption of the Federal law of 31.07.2020 N 248-FZ (an edition of 11.06.2021) "About the state control (supervision) and municipal control in the Russian Federation" (further - law No. 248-FZ) [2] came into force the upgraded legislation on control and supervising activity including in the sphere of management of land resources. According to Chapter XII of the Land Code, state land supervision, municipal land control and public land control are carried out in Russia [1]. The main task of control and supervisory reform is to shift the focus from conducting inspections to preventing violations, to give the subjects of inspections more guarantees when interacting with state inspectors, and to simplify this process [13].

The current state of legislation demonstrates the impossibility of correctly distinguishing between control and supervision, since there is no terminological unity even within individual acts. Suppose it is permissible to say that the prosecutor's office carries out supervision in a reference form, but this is perhaps the only correct example against which legislative confusion can be demonstrated by any act that uses the wording of the type "control (supervision)," "control (supervision) body." The problem under consideration, being a longstanding theoretical issue, was and remained unresolved, since the semantic words "control" and "supervision" are close [9].

The rules for interaction of federal executive bodies exercising state land supervision with bodies exercising municipal land control are established by a decree of the Government of the Russian Federation dated 26.12.2014 N 1515 (ed. From 28.11.2019) [1.6]. On the basis of paragraph 1 of Art. 29 of Law N 248-FZ the inspector, in particular, is obliged to timely and fully exercise the powers granted in accordance with the legislation of the Russian Federation to prevent, detect and suppress violations of mandatory requirements, take measures to ensure the execution of control decisions of the (supervisory) authorities, up to the preparation of proposals to apply to the court with a request for the enforcement of the order, if such a measure is provided for by law [8].

Consequently, the failure to exercise powers to prevent, detect and suppress violations, as well as the failure to take measures to ensure the execution of decisions of control (supervisory) bodies, will be recognized as inaction in relation to the performance of official duties.

Land control and supervision carried out by the Federal Service of State Registration, Cadastre and Cartography, the Federal Service for Veterinary and Phytosanitary Surveillance, the Federal Service for Supervision of Environmental Management and their territorial authorities is necessary to assess compliance by individuals and legal entities with mandatory requirements for the use and protection of land plots and other real estate, for violation of which administrative, criminal and disciplinary liability is provided (Article 74, 75 of the Code of Criminal Procedure of the Russian Federation) [1]. 
Administrative responsibility occurs in accordance with the Code of Administrative Offenses of the Russian Federation from 30.12.2001 N 195-FL (ed. From 01.07.2021, with rev. and additional, statement. in force from 01.10.2021, hereinafter - CAORF). Among the most frequent violations is the unauthorized occupation of a land plot or its part (Article 7.1 of the Code of Administrative Offenses of the Russian Federation), damage to land (Article 8.6 of the Code of Administrative Offenses of the Russian Federation). The number of violations of land laws and disputes "is quite large and tends to grow steadily over a relatively short period of time. This is due to the specificity and complexity of land offenses "[15].

Law No. 248-FL divides control verification measures, according to comments in the Review: "Reform of control and supervision: what has changed since July 1, 2021" (Consultant Plus, 2021), into two groups: "contactless" (when there is no interaction with a controlled person) and "contact." "Contactless" methods (monitoring compliance with mandatory requirements (safety monitoring) and field examination) can be used for any type of control [13].

Also, "in the light of the current processes of digitalization and reform of control and supervisory powers (both of these processes affect, inter alia, the information exchange between different entities of legal relations), the question of the implementation of those managerial functions and public services provided to private individuals is no less controversial" [10]. The list of "contact" methods of verification should be established in the regulation or law on a specific type of control. Such methods can be documentary inspection, on-site inspection, control procurement, monitoring purchase, sampling control, inspection visit, raid inspection [2, 13].

"Contact" checks can be carried out on a planned and unscheduled basis, as before. We have defined detailed rules for each event. The measures differ in the set of permissible control and supervisory actions. These include examination, inspection, questioning, requesting documents, experiment, etc. [6, 13]. The terms of documentary, field inspection, raid inspection are established by law in 10 (ten) working days, and the term of the inspection visit is 1 (one) working day.

In the development of Law No. 248-FL, quite a few government decisions and orders of state bodies have now been adopted. A list of these regulations relating to land supervision activities is given in table 1 .

Table 1. List of Normative Legal Acts adopted as a follow-up to Law No. 248-FL concerning Land supervision activities

\begin{tabular}{|l|l|}
\hline № & \multicolumn{1}{|c|}{ Name of Regulatory Act } \\
\hline 1 & $\begin{array}{l}\text { The Decree of the Government of the Russian Federation dated 30.06.2021 N 1081 "On Federal State Land } \\
\text { Control (Supervision)" (together with the "Regulation on Federal State Land Control (Supervision)") }\end{array}$ \\
\hline 2 & $\begin{array}{l}\text { The Decree of the Government of the Russian Federation dated 28.04.2021 N 663 (ed. From 06.10.2021) "On } \\
\text { approval of the list of types of federal state control (supervision), in respect of which the mandatory pre-trial } \\
\text { procedure for considering complaints is applied" }\end{array}$ \\
\hline 3 & $\begin{array}{l}\text { The Decree of the Government of the Russian Federation dated 16.04.2021 N 604 (ed. 15.07.2021) "On } \\
\text { Approval of the Rules for the Formation and Maintenance of a Unified Register of Control (Supervisory) } \\
\text { Measures and on Amending the Decree of the Government of the Russian Federation dated April 28, 2015 N } \\
\text { 415" }\end{array}$ \\
\hline 4 & $\begin{array}{l}\text { The Order of the Ministry of Economic Development of Russia dated 31.03.2021 N 151 "On standard forms of } \\
\text { documents used by the control (supervisory) body" (Registered with the Ministry of Justice of Russia } \\
\text { 31.05.2021 N 63710). }\end{array}$ \\
\hline 5 & $\begin{array}{l}\text { The Order of the Federal Service of State Registration, Cadastre and Cartography of 09.07.2021 N P/0303 } \\
\text { "About the approval of the List of indicators of risk of violation of mandatory requirements at implementation } \\
\text { by Federal Registration Service and its territorial authorities of federal state land control (supervision)" (It is } \\
\text { registered in the Ministry of Justice of the Russian Federation 07.10.2021 N 65333, comes into force from the } \\
\text { moment of recognition by the Ministry of Economic Development of the Russian Federation which became } \\
\text { invalid for the order of 09.01.2018 N 7). }\end{array}$ \\
\hline
\end{tabular}

A unified register of control (supervisory) activities is being created (instead of a unified register of inspections by the The Prosecutor General's Office of Russia). The QR code must be on the inspection decisions. According to it, any interested person will be able to view the verification information in the registry [13].

In modern conditions, when the global Russian program "Digital Economy of the Russian Federation" is being implemented in our country, the preventive activities of control and supervisory bodies should fully correspond to the new achievements of technological progress and take into account all "end-to-end" digital technologies enshrined in this program [12].

However, "the one-sided digitalization of state control and supervision in the absence of legal mechanisms providing for the introduction of" end-toend "digital technologies in the control and supervisory activities of executive authorities can lead to a significant technological lag in Russia from other, primarily Western, countries and will seriously question the success and effectiveness of the reform of state functions for control and supervision" [12]. The law gives priority to preventive measures in relation to 
control and supervision [13]. Preventive measures

include those indicated in Figure 1.

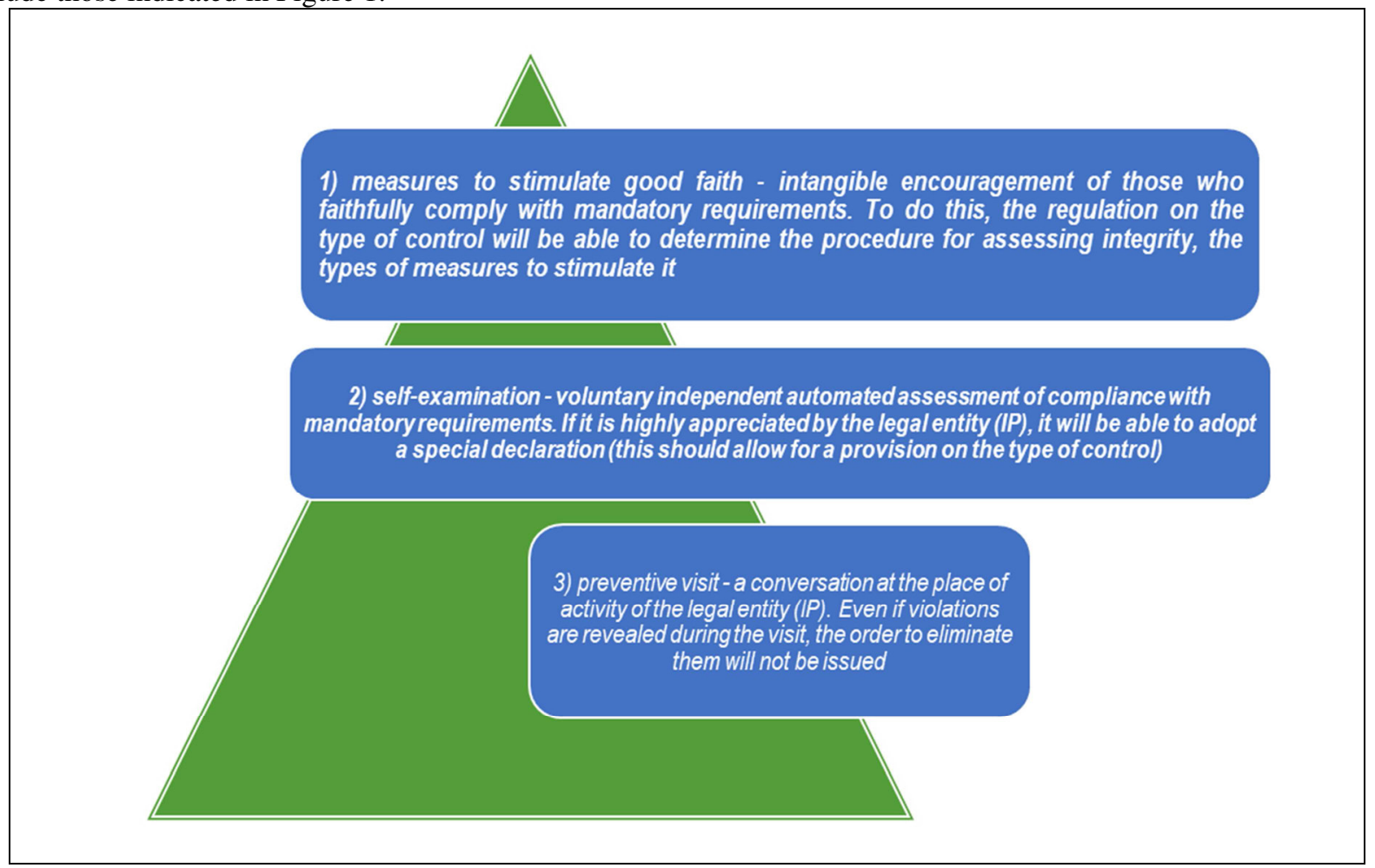

Fig. 1. List of Preventive Measures

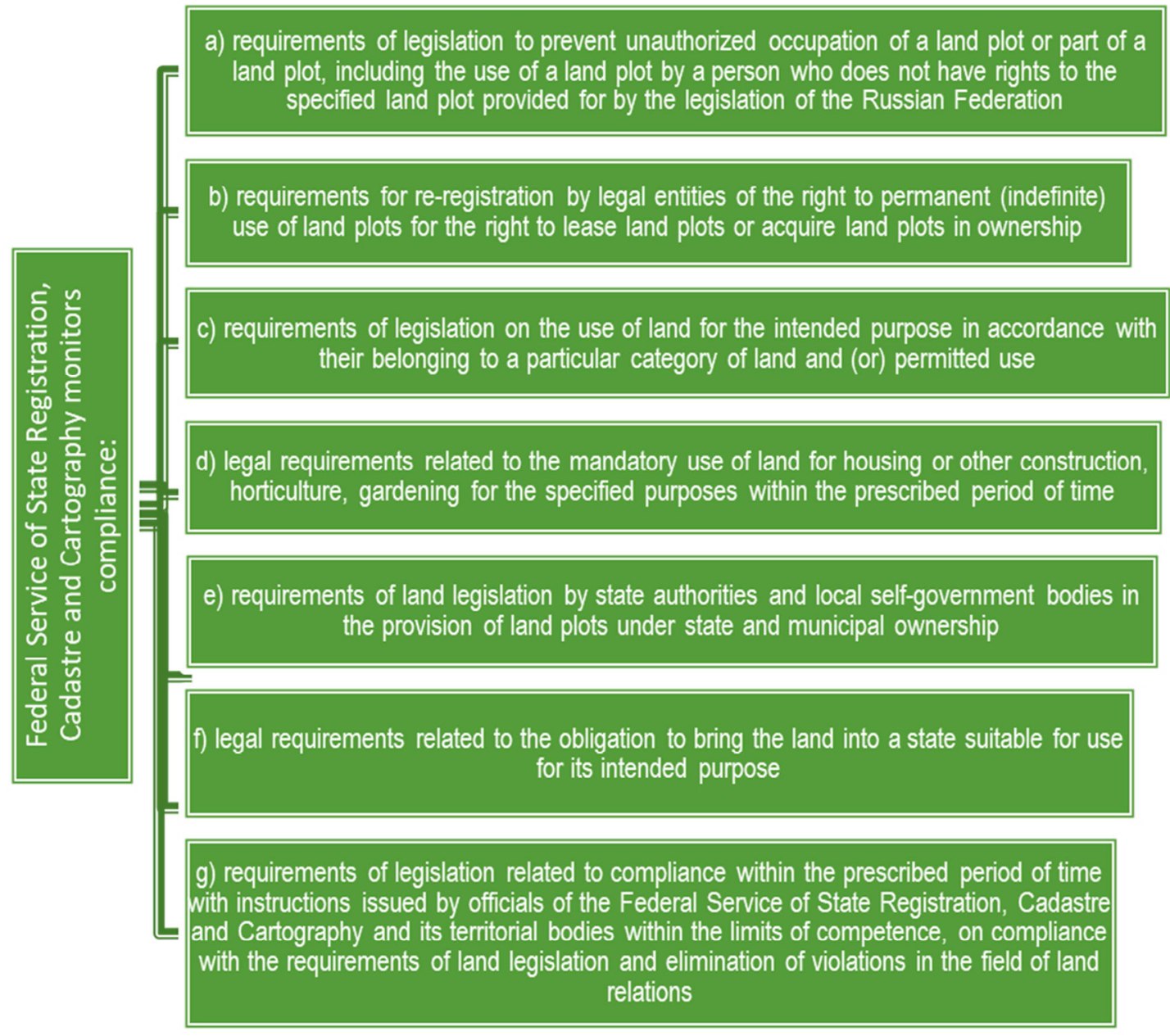


Fig. 2. Powers of Federal Service of State Registration, Cadastre and Cartography in Terms of Compliance with the Requirements of Land Legislation.

Land plots are to be classified as risk categories in accordance with the established criteria [6, 13]. Inspections scheduled for 2021 should be carried out in accordance with the annual plans for scheduled inspections of legal entities and individual entrepreneurs for 2021, approved in accordance with the Law on the Protection of the Rights of Legal Entities (part 7 of article 98 of the Law on State and Municipal Control). Federal Law of 26.12.2008 N 294-FZ (ed. From 11.06.2021) "On Protection of the Rights of Legal Entities and Individual Entrepreneurs in the Exercise of State Control (Supervision) and Municipal Control" [16].

The powers of Federal Service of State Registration, Cadastre and Cartography in terms of compliance with the requirements of land legislation are shown in Figure 2 [7].

\section{Conclusion}

The main conclusion that needs to be made on the basis of the above material is the fact that during $2020-2021$ there was not only a modernization of the Russian legislation on control and supervisory activities in the field of land management, but the very activity of land control (supervision) as the main function of managing both land resources and other real estate has changed significantly.

\section{References}

1. Land Code of the Russian Federation dated 25.10.2001 No. 136-FL (as of 12.10.2021). Retrieved from the reference and legal system Consultant Plus.

2. Federal Law of 31.07.2020 N 248-FL (ed. From 11.06.2021) "On State Control (Supervision) and Municipal Control in the Russian Federation. Retrieved from the reference and legal system Consultant Plus.

3. Federal Law of 11.06.2021 N 170-FL "On Amendments to Certain Legislative Acts of the Russian Federation in Connection with the Adoption of the Federal Law" On State Control (Supervision) and Municipal Control in the Russian Federation. Retrieved from the reference and legal system Consultant Plus.

4. Federal Law of 01.07.2021 N 273-FL "On Amendments to Certain Legislative Acts of the Russian Federation".
5. Federal Law of 01.07.2021 N 275-FL "On Amendments to Certain Legislative Acts of the Russian Federation".

6. Decree of the Government of the Russian Federation dated 30.06.2021 N 1081 "On Federal State Land Control (Supervision)" (together with the "Regulation on Federal State Land Control (Supervision)"). Retrieved from the reference and legal system Consultant Plus.

7. G.N. Barsukova, E.V. Yarotskaya, K.A. Yurchenko, Land management: Textbook (Kuban State Agrarian University named after I.T. Trubilin, 2021) 288 p.

8. P.S. Dolgopolov, Responsibility for actions (inaction) of officials. Retrieved from SPS Consultant Plus.

9. M.D. Kurdyumov, On the problem of the relationship between the terms "control" and "supervision" on the example of power activities to ensure competition in the banking sector, Russian Justice, 2, 23-26 (2021). DOI: 10.18572/0131-67612021-2-23-26

10. S.A. Lipski, Changes in the composition of subjects of land legal relations, Materials of the All-Russian Scientific Conference dedicated to the memory of Professor F.M. Rudinsky, pp. 129-131 (Moscow)

11. S.A. Lipsky, Legal support of state registration of real estate (KnoRus, Moscow, 2021) p. 228.

12. A.V. Martynov, Using modern digital technologies in the preventive activities of control and supervisory bodies of the executive branch, Lawyer, 10, 48-56 (2020). DOI: 10.18572/1812-3929-2020$10-48-56$

13. Review: "Control and oversight reform: what has changed since July 1, 2021." Retrieved from the reference and legal system Consultant Plus.

14. L.P. Podbolotova, Change of powers of Federal Service of State Registration, Cadastre and Cartography in 2020 taking into account the decree of the Government of the Russian Federation dated 07.09.2020 N 1369, Digitalization of land use and cadastre: trends and prospects. Proceedings of the International Scientific and Practical Conference 25 September 2020. pp. 332-339 (2020)

15. L.P. Podbolotova, Analysis of Judicial Statistics on Land Disputes as a Land Administration Tool/Audit Statements, Quarterly scientific and practical journal, 4/20, 112-115 (2020)

16. V.E. Polyakova, Scheduled inspections of legal entities. Retrieved from SPS Consultant Plus (2021). 